ÉGYPTE monde arabe

\section{Égypte/Monde arabe}

15 | 2017

Migrations vues d'Égypte - mobilisations et politiques

\title{
Voicing refugeeness: Sudanese struggles for belonging in Egypt and Israel
}

Pauline Brücker

\section{(2) OpenEdition \\ 1 Journals}

Electronic version

URL: https://journals.openedition.org/ema/3671

DOI: $10.4000 /$ ema.3671

ISSN: 2090-7273

\section{Publisher}

CEDEJ - Centre d'études et de documentation économiques juridiques et sociales

\section{Printed version}

Date of publication: 5 June 2017

Number of pages: $95-123$

ISBN: 2-905838-93-0

ISSN: 1110-5097

\section{Electronic reference}

Pauline Brücker, "Voicing refugeeness: Sudanese struggles for belonging in Egypt and Israel", Égypte/ Monde arabe [Online], 15 | 2017, Online since 05 June 2019, connection on 07 July 2022. URL: http:// journals.openedition.org/ema/3671 ; DOI: https://doi.org/10.4000/ema.3671 


\title{
Pauline Brücker
}

\section{VOICING REFUGEENESS: \\ SUDANESE STRUGGLES FOR BELONGING \\ IN EGYPT AND ISRAEL}

\begin{abstract}
This article examines the mobilization strategies used by asylum seekers and statutory refugees to counter restrictive asylum policies that deprive them of their legal status - and therefore of any political affiliation. It examines two cases of mobilization of Sudanese asylum seekers: the Mustapha Mahmoud mobilization in Cairo, Egypt (2005) and the March for Freedom, followed by various demonstrations, in Israel (2013-2014). The use of a "voice" strategy clearly reveals a decision to make a group visible and to go against orders from the powers that be to remain silent, or even invisible. The exclusion faced by asylum-seekers as a result of the denial of the right to refugee status is an initial resource that federates the individuals concerned and allows them to form a social group that shares mutual interests. This mobilization then seeks to reverse the stigma created by restrictive asylum policies (economic migrants usurping the system in the Egyptian case, and infiltrating it in the case of Israel). This reversal of stigma requires discursive strategies and a specific staging of mobilization that involves international systems of protection, international refugee and human rights laws, and the responsibilities of the UNHCR and States. The repression of the two movements by the Egyptian and Israeli security forces respectively led to a shift from a "voice" to an "exit" strategy, in which mobility seems to embody both an exit route from an aborted mobilization and a gateway to a new potential foundation for political affiliation. The article also examines the potentially transnational scope of the protest struggles of asylum seekers.
\end{abstract}




\section{INTRODUCTION ${ }^{1}$}

In the study of social sciences, the profile of the refugee has long shared one common feature, despite its legal and social disparities: deprivation of the political and civic rights that are reserved to national citizens (Arendt, 2010). Refugees evolve within the interstice of nation-states, as they no longer fully belong to their home state and do not yet belong to a new host state (Haddad, 2008). They do not legally belong to any political community: seeking asylum is precisely a quest for a transfer of belonging from a state of origin that is unable to provide protection to a new - and as yet uncertain - state of adoption. Refugees therefore remain confined to forms of social invisibility in both states, as their actions are rendered invisible by the power structures (Sayad, 1999). Indeed, for Ataç et al., "invisible politics emerge out of everyday practices in the context of border and integration regimes. (...) Such political practices are invisible as they are not captured as such by dominant regimes of visibility - they rather attempt to elude their gaze and seek to remain imperceptible" (Ataç et al., 2015:6-7). Nevertheless, this invisibility can be questioned today, as migrants increasingly engage in visible struggles to defend their rights as asylum-seekers in their host countries and oppose their irregularization, precarization, and isolation (Oliveri, 2015). Borders have become a place for contestation, and illegal crossings a means of enforcing migration strategies (Veron, 2014). Examples range from the assaults in Calais or Ceuta (Migreurop, 2006), illegal crossings of the Aegean Sea

This article looks at how asylum-seekers choose to resort to visibility and voicing ${ }^{2}$ strategies to defend their right of belonging in their host countries. As such, it is not concerned with the political and social gains that may be made from mobilization, but rather with its strategic dimension (Dobry, 2009): that is, the process by which asylum seekers and refugees use and develop their specific resources in order to impose themselves as political actors through visible mobilizations. Accordingly, the notion of "belonging" is addressed here as an incentive for mobilization, as a tool in the process of mobilizing, rather than as its ultimate goal. As this paper will show, however, the identity of the recipient of the claim of belonging (the UNHCR or the State) will affect the modes and discourse of actions.

This article addresses the case of mobilizations in Egypt and Israel by Sudanese refugees, who, between the time of the sit-in in Mostapha Mahmoud Square (Cairo, Egypt, September-December 2005) and the March for Freedom (Israel, 2013-2014), collectively sought to address their rights as

1. The author would like to thank Charles Heller for his contribution and support in the long maturation of this article and Ibrahim Awad and Karine Bennafla for their precious comments in its latest version.

2. I refer here to the distinction made by Hirshman, in Exit, Voice and Loyalty. 
asylum-seekers. ${ }^{3}$ In looking at these specific struggles, my intention is to bring empirical insight to migrants' struggles in a specific context: that of urban asylum seekers in the "Global South". The sociology of migration has focused mainly on "belonging" in Western countries, and has left the issue of integration and political membership in other regions of the globe as a topic of marginal interest. The political engagement of migrants has mainly been studied through the involvement of diasporas with the affairs of the home states (Jaulin and Smith, 2016; Sheffer, 2003; Vertovec, 2005), and the political ties therefore remain with the country of origin rather than being transferred to the host country. The focus has been on migrants' political connections to their home countries in Middle Eastern studies as well, as is the case with the political engagement of Palestinian or Iraqi diasporas (Al-Husseini and Signoles, 2009; Baser, 2015; Brand, 2006). The latter case may also point up the gestation of the idea of the "right to return" in the region and its impact on academic research. Finally, despite the rise of transnational theory of migration, little attention has been devoted to the possible transnationalization of the migrant struggle (Shami, 1996).

On the other hand, as far as non-national mobilization is concerned, the sociology of social movements has focused mainly on foreign migrant workers (Jounin, 2014). The theory of resource mobilization, which is a pillar of the sociology of social movements (Neveu, 2011), makes migrants "unlikely" actors in the fields of mobilization, on the basis of their allegedly intrinsic lack of resources: as a consequence, their mobilization is "improbable", and often requires powerful support from external actors such as NGOs or activists (Mathieu, 1999; Pette, 2016). In contrast, I focus here on the process by which an apparently "powerless" group develops specific resources that are invested in visibility strategies. Attention in this article is therefore devoted to the "environmental" aspect of mobilization: that is, the geographic and spatial localities of actions as a resource creator (Hmed, 2009).

3. As a methodological insight on this research, I would mention that this article is based on fieldwork carried out in Egypt (mainly Cairo and Alexandria) and Israel (Tel Aviv, Beer Shiva, Netanya, Arad, and the Holot Detention Centre) between January 2013 and January 2016. Ethnographic research was conducted with both groups of refugees and asylum-seekers on both sides of the border and with activists, NGOs, and other actors who assist and support refugees. In the case of the 2005 Mustapha mobilization, research was carried out a posteriori through interviews with Sudanese individuals who were formerly involved with the movement and who lived in the square between September and December 2005. Pictures taken by participants in the sit-in have also been used to provide visual insights into the geographical setting of the movement. In the case of Israel, some events were witnessed directly (demonstration in Tel Aviv), while others (such as the March for Freedom) were viewed through interviews with Sudanese, Israeli, and international supporters, but were unfortunately not witnessed directly. 
Finally, I must mention the very specific contexts in which the movements I observed took place. On the one hand, despite its 2011 ambitions for democratic reform, Egypt is still ruled by an authoritarian regime that prevents visibility strategies and keeps opposition voices illegal and invisible (Vannetzel, 2008). The post-2011 context has, however, enabled researchers to shed new light on voicing strategies in Egypt, and it is in this context that I intend to focus on the situation of non-citizens vis-à-vis those voicing strategies in a pre-revolutionary context. 2005 was a turning point in Egyptian affairs on several fronts: Kefaya ("Enough"), the civil movement opposing the Mubarak regime sometimes considered as being a retrospective indicator of the 2011 contestations, was on the rise, while the State was organizing the first open elections in many years (Néfissa, 2007).

In Israel, on the other hand, the opposition stage has been dominated by the Palestinian issue in recent decades (Lamarche, 2013), although socio-economic problems specific to Israel were the subject of conflict in 2011. The historically low rate of non-Jewish foreigners in Israel meant that non-Jewish migration-related issues were an extremely marginal part of, if not actually absent from, the public sphere. The sudden emergence of African asylum seekers on the streets of Israel went unnoticed, and attests to the rise of a new area of controversy in the country. Likewise, the Israeli political landscape gradually became affected by the strategic use of the "African refugee issue" by conservative parties to foster support for a nationalist and Zionist programme (Brücker, 2015). How and why did refugees in these two contexts decide to engage through voicing and visibility strategies?

I argue that the struggles led by Sudanese in Egypt and Israel are struggles for "belonging", using the term "political belonging" in a broad sense. In line with Isin's work on citizenship, I argue that "Rather than asking 'who is the citizen?' the question becomes 'what makes the citizen?'" (Isin, 2009):383). Isin understands citizenship to be a dynamic, fluid institution, defined not by a formal belonging to a national territory but rather by "acts of citizenship" that define "activist citizenship", as opposed to "formal citizenship". As he puts it, "The rights (civil, political, social, sexual, ecological, cultural), sites (bodies, courts, streets, media, networks, borders), scales (urban, regional, national, transnational, international) and acts (voting, volunteering, blogging, protesting, resisting and organizing) through which subjects enact themselves (and others) as citizens need to be interpreted anew" (ibid: 368). I ask how asylum-seekers manifest a desire and a right to belong to a specific community of rights by appearing on public stages as "refugees".

I will address how exclusion from belonging process implemented through changes in the granting of refugee status provides a first resource for action (I), leading to the construction of a collective movement using specific modes of action (sit-in/square occupation and marches) and a collective refugee identity as resources (II). Finally, I will address the issue of how the temptations of exit and loyalty have emerged as alternative modes of political expression (III). 


\section{EXCLUSION FROM BELONGING: A RESOURCE FOR MOBILIZATION}

Belonging is an issue of particular complexity for refugees. Caught between two states, a refugee can find a form of belonging by being absorbed into a new political community. This may occur through the granting of formal refugee status (and later on, through naturalization, when and where it is possible). Obtaining legal status - that is, what I consider here as a form of legal belonging - allows for social belonging as a lawful co-resident of a common place. Exclusion from belonging, conversely, can be defined as the denial of refugee status, which deprives individuals not only of their rights as refugees, but also of their rights as co-residents, which legitimizes their presence on foreign soil. In our Egyptian and Israeli cases, dramatic or sudden changes in asylum and migration policies that restrict access to refugee status lead to the exclusion of belonging of these asylum seekers. As I argue it, this exclusion provides refugees with a resource for mobilization and leads to the ad hoc construction of an opposition group.

In Egypt, the UNHCR, which is responsible for the administrative management of asylum seekers and refugees, ${ }^{4}$ orchestrates "refugee status determination" (RSD), the process that defines who may (or not) belong to the international refugee community. In 2004, a long waiting period had developed due to insufficient resources within the UNHCR to respond to the growing numbers of Sudanese asylum seekers fleeing to Egypt. Insaf, who arrived in Cairo in 1998 but as yet had no status, remembers:

"The problem was that our processes would not go on. We came to ask for news about our file and process, but nothing was coming up. Everyone was coming, they would take our papers, and would say 'come, go, come, go' and nothing was happening". ${ }^{5}$

This pressure on the UNHCR office resulted in the creation of the category of "asylum seekers", to whom a temporary "yellow card" was given to protect them from refoulement. In addition, the UNHCR changed its recognition criteria in 2003, preferring the adoption of the 1969 OUA Convention definition rather than that of the 1951 Convention in order to facilitate recognition and

4. Egypt, which is a party to the 1951 Convention on Refugees, and its 1967 Additional Protocol in 1981 and the OAU Convention in 1980, has no national legal and administrative system to deal with refugees. According to a 1954 Memorandum of Understanding, it is the UNHCR's responsibility to ensure the management of refugees.

5. Interview with Insaf, March 2015, Cairo, Egypt. 


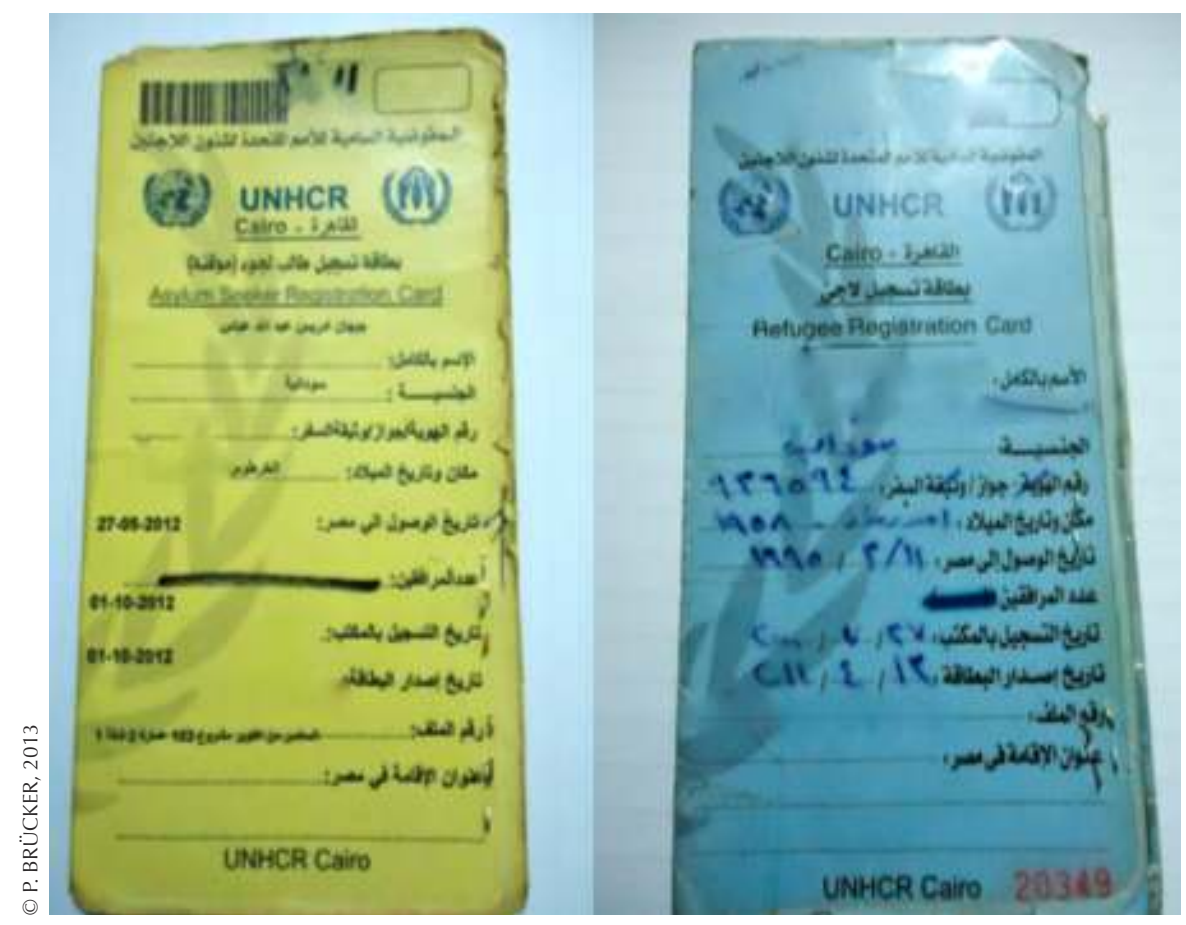

Figure 1. UNHCR Refugee (blue) card and asylum-seeker (yellow) cards in Egypt

speed up the overall RSD process. ${ }^{6}$ Sudanese were not aware that a status based on the 1969 Convention would exclude them automatically from resettlement. In late 2004, the UNHCR suspended all RSD and resettlement processes for Sudanese citizens: a Sudanese asylum seeker could no longer expect to have his demand processed for an undetermined period. The rationale for this decision was highly political: the ongoing discussions in 2004 on a forthcoming peace agreement between Khartoum and the main southern opposition party, the SPLM, led the UNHCR to decide that peace and stability would shortly return to Sudan. Additionally, the Four Freedoms agreement, which ensured freedom of movement between Egypt and Sudan, was enforced. As a sign of an improvement of Egypt-Sudanese relations, which had been at a low point since the attempted assassination of former President Mubarak in 1995 which had ended the no-visa policy between the two neighbours, the enforcement of the agreement also called for a freeze in refugee status grating.

6. The UNHCR witnessed a rise from about $30 \%$ of cases of recognition to $60 \%$ because of the application of this extended definition of refugee status (Grabska, 2006). 
The ending of RSD processes for Sudanese was, therefore, an act that evidenced a very welcome peace between South and North Sudan and a warming of diplomatic relations between Egypt and Sudan. From the UNHCR's perspective, Sudanese citizens would soon return to their newly peaceful country, which would strategically save some of the organization's resources. This decision was however not in line with the processes laid down in UNHCR's cessation clause, ${ }^{7}$ nor did it comply with the UN's recommendations of the time vis-à-vis the Darfur crisis, which repeatedly emphasized the dramatic scale of the humanitarian crisis. It therefore contradicted the UNHCR's normative framework.

This freeze in determination of refugee status and resettlement created a "waiting zone" in which communications with the office were limited (Brücker, 2013). Kalthoum arrived in Cairo from Khartoum in 2004 with her three children to meet her husband, who had left the Sudanese capital a few months earlier. She recalls:

"When he (her husband) arrived in 2004, the files for Sudanese were still open. Resettlement, RSD, the files were in process. But when we tried to make an appointment for RSD, we were told that there were no longer any appointments for the Sudanese. Why? Because there was peace between the North and the South (...). It is the UNHCR who told us 'no, today, it is not possible, there is no appointment. Because your file, your Sudanese file, it is over'. There were many people who had appointments, everyone was there, waiting. An employee came down and told us 'the Sudanese file are closed because of the peace, the peace between the North and the South'. One man said 'I am from the East'. She said 'The Sudan is one, and files are no longer accepted. Neither for the North, nor for the South, nor for the East, nor for the West. Sudan is one, and we take no files. Maybe in six months, God willing, we will see. After six months, they told me again, 'six months'. Six months later I asked them 'what is going on with the Sudanese file, it is open or closed?'. They told me 'six more months'. Then what did the Sudanese do? They staged a sit-in in Mustapha Mahmoud Square." ${ }^{8}$

These unilateral policy changes weakened the links with the UNHCR, which was perceived as an agent working for the Egyptian regime - which was itself close to Omar el-Beshir - and thus as working against refugees' interests. Confusion and misunderstanding emerged as the sole modes of interaction between agents of the international organization and refugees, and yet the UNHCR remained the only recipient of their complaints. It was

7. The cessation clause in the case of Rwanda refugees only applied in 2013, more than fifteen years after the 1994 genocide and the fighting in North-Western Rwanda in 1997-1998 (UNHCR, 2013).

8. Interview with Kalthoum, April 2015, Cairo, Egypt. 
the only administration that was in a position to provide them with refugee status and resettlement opportunities, so people would gather daily in front of the main gate:

"It was a while that people had been waiting in front of the UNHCR. They would not give us any response, nothing. So there were more and more people, from Darfur, from the South. Everyone had problems. And no one had anyone else other than the UNHCR that could deal with their problems, so they all came in front of the office" ${ }^{\prime \prime}$ recalls Insaf. ${ }^{9}$

The UNHCR gate became a space of socialization: people met and talked, waiting to receive news of their files, exchanging information, and in the end creating social ties and networks. While the exclusion of belonging is an individual sanction in that it affects each person or household in the context of their particular asylum process, it also becomes a collective sanction, as they are all excluded based on their nationality. Remaining at the gate, waiting and gathering at the same place on a daily basis emerged as a resource. As Bayat argues, collective presence in certain locations may indeed create and feed contestation movements (Bayat, 2009).

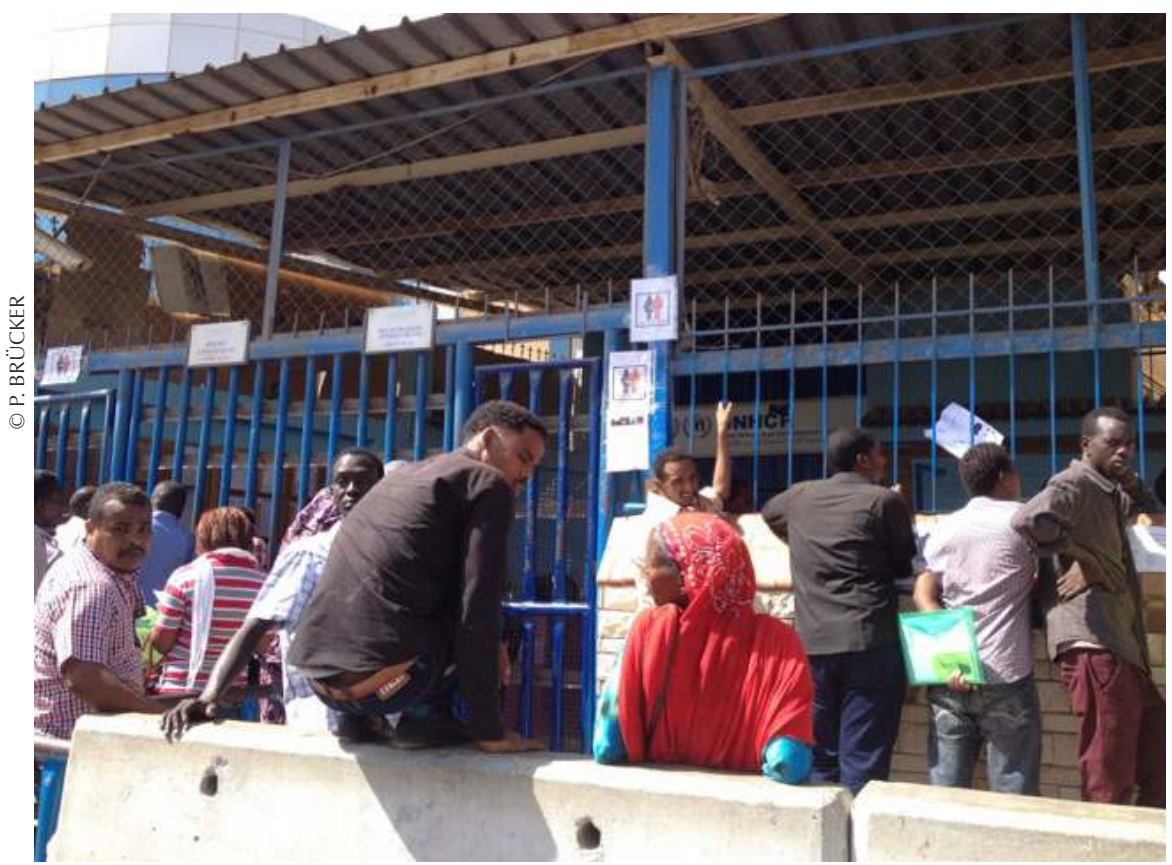

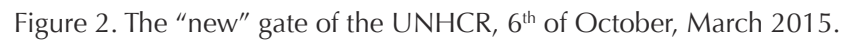

9. Interview with Insaf, March 2015, Cairo, Egypt. 
On the Israeli side, African migration began in the late 1990s, but the number of entries became really significant in 2006. At that time, the migrants entering Itsrael were mostly Sudanese arriving from Cairo (Brücker, 2015). The political response to the arrival and settlement of African migrants was fairly improvised until the late 2000s (Anteby-Yemini, 2008). But the growing numbers of newcomers led to a progressive deterioration in their living conditions due to the adoption of exclusion policies, especially after the 2009 elections and under Benyamin Netanyahu's ultra-nationalist government. The handover of RSD from the UNHCR to the government drastically reduced the number of asylum demands that were reviewed and approved (see Table 1). Formal refugee status was made very difficult to obtain,$^{10}$ since the Israeli state considered the grounds for asylum claims to be illegitimate (HRW, 2014). ${ }^{11}$ The increasing difficulties experienced by Sudanese and Eritreans in obtaining refugee status led to larger numbers of migrants being classified as illegal and unlawful in Israel.

\begin{tabular}{|c|c|c|c|c|}
\hline Year & $\begin{array}{c}\text { Total number } \\
\text { of demands }\end{array}$ & $\begin{array}{c}\text { Total number of } \\
\text { accepted demands }\end{array}$ & $\begin{array}{c}\text { Number of } \\
\text { rejected demands }\end{array}$ & $\begin{array}{c}\text { Recognition } \\
\text { rate } \%\end{array}$ \\
\hline 2013 & 497 & 6 & 491 & 1.2 \\
\hline 2012 & 1,137 & 6 & 1,131 & 0.57 \\
\hline 2011 & 4,287 & 8 & 4,279 & 0.19 \\
\hline 2010 & 3,366 & 6 & 3,360 & 0.17 \\
\hline
\end{tabular}

Table 1: Asylum demands and recognition rate in Israel, 2010-2013.

Source: Hotline, 2012 \& 2014

The concomitant rise of the "infiltration" rhetoric" in the political arena and the media also led to the criminalization of migrants, underscoring a shift from improvisation to state repression (Anteby-Yemini, 2008). The revival of the 1954 Anti-Infiltration law, which had originally targeted Palestinians living

10. From 2009 to 2014, only two Eritreans asylum applications were accepted.

11. Asylum claims were not accepted, as the government considered Africans to be economic migrants who had fled Egypt to escape misery. Moreover, the forced military enrollment of Eritreans is not considered to be persecution by Israel.

12. The government also decided in 2009 to process all asylum demands itself through a newly created unit, the "Refugees and Infiltrators Unit". The choice of the words "immigration" and "infiltrators" to classify the situation betrays the State's attitude to the issue. 
in neighbouring countries, ${ }^{13}$ led to an association between African asylum-seekers and the Palestinian section of the resistance in the 1950s and 1960s. Under the 2012 amendment and those that followed, asylum-seekers could be punished with imprisonment for crossing the Egyptian-Israeli border illegally (HRW et al., 2014). The term "infiltration" also plays ambiguously with the idea of an external threat to a collective existence: this rhetoric adds a form of social exclusion to the legal one.

In addition to legal and social exclusion, this law also implemented physical and spatial exclusion through the detention of "infiltrators". Previously, a large majority of migrants had been detained for period ranging from a few weeks to a few months before being released, but the new amendment provided for indefinite detention until deportation. For example, Abdel Moniem, who arrived in Israel in early 2012, was jailed after crossing the border between Egypt and Israel. In June 2012, because of the new amendment to the anti-infiltration law, he was informed that he would be kept in prison indefinitely until he was sent back. He was denied the right to submit an asylum demand. He recalls:

\footnotetext{
"They took us to the tribunal and then we discovered that on that day, 18 June 2012, there was a new law, the Anti-Infiltration law. When we saw the judge, he told us that we would stay in prison for three months in a closed facility and then we would see what happened. If they would release or keep us, we did not know. (...) Two months later I saw the judge again and he told us that we would stay here until the government deported us back to Sudan. I told the judge about my problems in my country, including racism, discrimination and genocide (...). He told me 'there is no asylum in Israel. You will stay here until the government decides to send you back.' That was his response. That I should stay in prison and that there was nothing called asylum". ${ }^{14}$
}

In September 2013, the Supreme Court declared the 2012 amendment illegal and called for the liberation of detained refugees within three months. While most of Moniem's fellow prisoners were released, he was transferred to

13. At its origin, the 1954 Prevention of Infiltration law covered "(1) a national or citizen of the Lebanon, Egypt, Syria, Saudi-Arabia, Trans-Jordan, Iraq, or the Yemen; or (2) a resident or visitor in one of those countries or in any part of Palestine outside Israel; or (3) a Palestinian citizen or a Palestinian resident without nationality or citizenship or whose nationality or citizenship is doubtful and who, during said period, left his ordinary place of residence in an area which has become a part of Israel for a place outside Israel". (Article1). For the full content of the law, see: https://www.jewishvirtuallibrary.org/jsource/History/1954law.pdf (last consulted 03/02/2017).

14. Interview with Abdul Moniem, April 2015, Netanya, Israel. 
the newly-constructed "open facility", the Holot Center. He remembers this transfer and the perspective of endless detention as the backbone of their mobilization:

"I arrived in Holot on 13 December 2013. (...) You could see the anger in people's eyes. There was something ready to explode inside people. (...) We had decided that we would not stay here, because Holot was a lifetime prison. The Israeli government was telling us that we would stay in Holot until the problems in Sudan got better. The immigration told us that they were providing us with a bed, food and money, and that we should be happy. But life is not a bed or food. I am a human being. I have the right to live like one. Even if I am not in my country. So I spoke with people. We discussed together about this situation, which was no longer possible."15

The multifaceted exclusion (legal, social, and spatial) these people suffered led to the rise of a resource for collective action based on feelings of resentment and anger, of not being listened to or understood. In both our Egyptian and Israeli cases, exclusion from belonging was implemented through a denial of legal status, which might be termed 'exclusion from legal belonging' - by opposition to what might be social belonging, for instance. ${ }^{16}$ This exclusion portrayed migrants as not being legitimate recipients of the assistance and protection granted to refugees according to the standards of international and customary law. This exclusion from their "right to have rights" as refugees and asylum seekers and from the possibility of legal residence in their host country removes what makes them human, and hence excludes them from a political community of rights (Arendt, 2010), which triggers visible collective mobilization, which, I argue, is staged as a performance of civil belonging.

\section{REVERSING A STIGMA: SELF-STAGING AND VISIBILITY OF REFUGEENESS}

In opposition to this delegitimized profile and exclusion from the political community of rights, Sudanese resorted to a sit-in in front of the UNHCR's offices in Cairo, Egypt and to the "March for Freedom" in Israel, which left the

\section{Ibid.}

16. In this sense, legal belonging and social belonging may be the same thing, which would be a completely successful act of belonging, but we can also imagine those two forms of belonging in dissonance: a statutory refugee can benefit from legal belonging but be excluded from the social sphere, which underlines mechanisms of discrimination and the way they might undermine the strength of legal belonging. Conversely, an asylum seeker may not have gained a formal status but yet may feel integrated socially on the basis of common language, cultural traditions, religion etc. 
Holot Center in the Negev desert for Jerusalem, supported in the following weeks by demonstrations in Tel Aviv and a strike. Posters stating "We are Refugees" and the occupation of public spaces were used as a means of promoting an alternative representation of asylum-seekers to that conveyed by policy-makers from above. While these two sets of events clearly underscore the contextually different ways in which Sudanese issues evolved in Egypt and Israel, both mobilizations were nonetheless an attempt to reverse a negative "refugeeness" stigma.

\section{SIT-IN AND MARCHES: SYMBOLISM IN REPERTOIRES OF ACTION AND SPATIALITY AS A RESOURCE}

Both the Mustapha Mahmoud sit-in and the March for Freedom were improvised, in the sense that they were not planned in advance by a specific group of previously-mobilized individuals. This illustrates the gestation of "street politics" and the way - as Bayat argues it - in which mobilization can emerge not only from strong, solid political identities (here questioning the concept of an "activist career" (Matonti and Poupeau, 2004)) but also from daily forms of shared habitation (Bayat, 2009).

In the Egyptian mobilization, it was never anticipated that a collective sit-in would be started in front of the UNHCR. Yet most of the Sudanese leaders of the movement had benefited from international and refugee law courses organized by the FMRS at the American University of Cairo (Barbara HarrellBond, 2006) that not only enabled them to develop specific social networks and ties, but also provided them with solid knowledge of their rights as defined in international law and the UNHCR's responsibilities with regard to refugees. This undoubtedly played a role in the development of the 
contestations (ibid). The Sudanese referred constantly to international law and what the UNHCR's role and practices (in terms of RSD and resettlement) should be. ${ }^{17}$

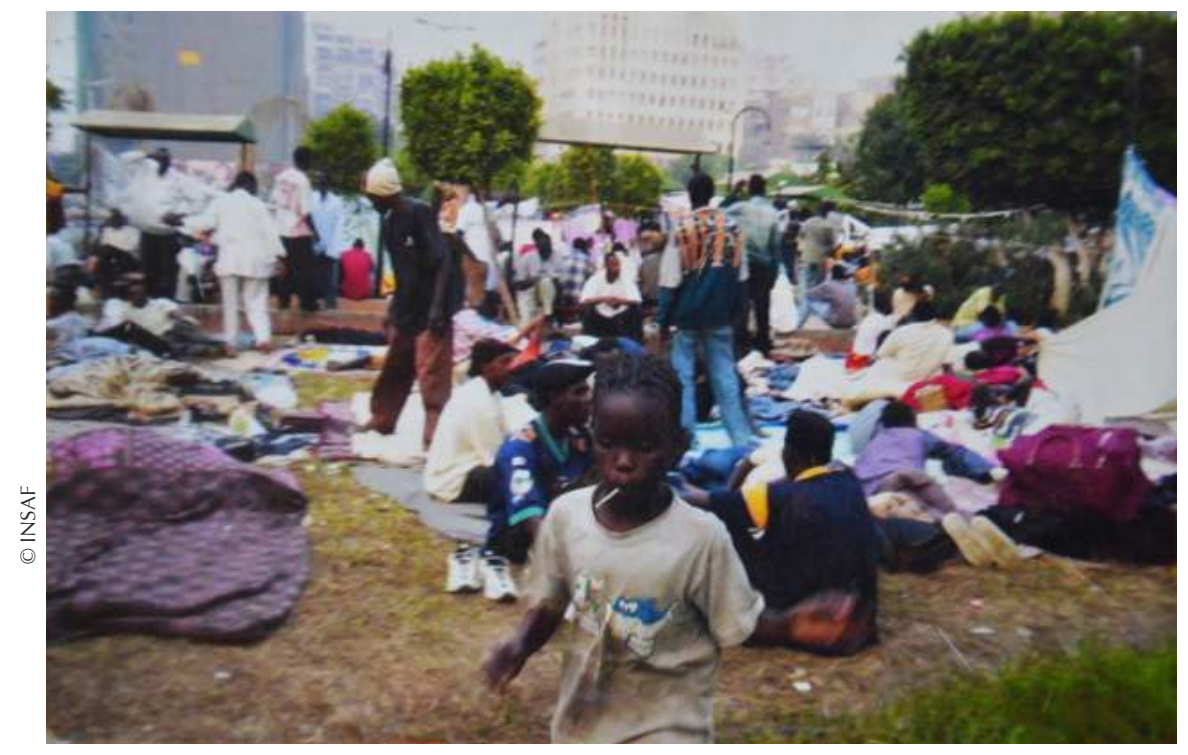

Figure 3. The Mostapha Mahmoud sit-in, Mohandessen, Cairo, October 2005

The mobilization started at the gate of the UNHCR administration, the place of collective co-presence. As a tool of socialization, it gave rise to an improvised gathering, a form of mobilization growing from the ground. Saleh, who became part of the leading committee of the sit-in, remembers:

17. Interestingly, the asylum seekers and refugees who met in Egypt (unlike the case in Israel) would all hold the UNHCR responsible for their status and asylum-related misfortunes. One might argue that this means there was a misunderstanding about the actual role of the UNHCR and resettlement opportunities, which are sovereign decisions on the part of resettlement countries, which were at the origin of much of the discontent with the agency. The UNHCR is only one actor, albeit the most obvious one to the refugees, within the international refugee protection regime. States that in principle have far more weight in the process often do not in practice. Host countries are also apparent to refugees, who live in them and may suffer from the inadequate level of the services these countries extend to them and of opportunities to earn a livelihood they find there. But resettlement countries are equally important actors, and even third countries that are neither host nor resettlement countries may also be considered to be actors because they contribute towards maintenance through international cooperation. 
"Each time you would go to the UNHCR, you would ask for news about your file, you would ask for the result, they would always say 'there is nothing'. So we met there, in front of the office, one wanted an appointment, another one wanted his result. We would stay close to the UNHCR until someone would find a solution, because life was tough outside. So we decided that we would stay in the office. But the soldiers told us that we could not stay here, so we went to the square. Next to the mosque. Because they would tell us that we could not stay in the street of the UNHCR, so when we asked them where to stay, they told us 'stay here'. So we stayed there. Sudanese would pass by, ask us what was going on, and we would tell them. Those who found themselves in our demands and claims joined us." 18

The "accidental" transportation of the protest from the small street where the office was located to the main square changed the scale of the mobilization and its visibility. Its location and the choice of the means of action - or rather the gradual transformation into a collective sit-in - was highly strategic: the location opposite the office is very well known to all refugees, and the ongoing and long-term presence of the group allowed for the gradual mobilization of a significant section of the Sudanese community. At the same time, concentration of the mobilization into one specific square did not disturb the established order too much, while nonetheless being highly visible. In the days and weeks that followed, hundreds of people joined the group in a spontaneous, collective movement, and at its peak it was estimated that between 2,000 and 4,000 refugees had gathered in Mustapha Mahmoud Square. ${ }^{19}$ The mode of action and its visibility therefore became a resource. The possibility of making political gains led other Sudanese to join in, and the sit-in became a not-to-be-missed opportunity. Ali, who was a teenager living in Cairo with his uncle at the time of Mustapha Mahmoud, recalls returning their flat keys to the owner and having no alternative in sight but to eventually take advantage of the sit-in:

«Little by little many people came to see them, living in the new camp, sleeping there. My uncle told me then: unless we sleep here, our case will never be reviewed. I told him that I had to go to school. He answered "no, if we go there, they will start to work the process. They will see we are serious". So we gave the key back to the owner, and we went there. ${ }^{20}$

18. Interview with Saleh, April 2015, Holot Detention Center, Israel.

19. See for instance Whitaker B. (2005) "20 killed as Egyptian police evict Sudanese protesters", The Guardian, 31 December 2005. http://www.theguardian.com/ world/2005/dec/31/sudan.brianwhitaker (accessed on 23/11/2014).

20. Interview with Ali, February 2013, Maadi, Egypt. 
Soon after its establishment, the UNHCR stated that Sudanese protesters were economic migrants and decided that accordingly they were not under the organization's protection. ${ }^{21}$ The symbolism of the demonstration was very powerful: Sudanese who settled in the street and called for the UNHCR to discharge its responsibilities, who had been disqualified by the very international institution that was in charge of refugee protection. The precarious situation faced by the refugees who made their presence known by resorting to this outdoor sit-in, and who had no other option but to remain there, in front of the UNHCR building, represented an opposition to the symbolic power of the international organization. ${ }^{22}$ Leaving everything behind to live in the square is a good example of the reversal of stigma: this was no longer the moment to disappear quietly into Egyptian society; it was time to stand before the Egyptian government and to the UNHCR and assert their dependency on the refugee organization and its responsibility for granting them a legal status. Through settlement in the street, refugeeness was stated in its humanitarian form, highlighting the vulnerability of the uncertain and unsecure life of asylum in the Egyptian context. The UNHCR was also portrayed by this mobilization as the visible face of the international protection regime.

In Israel, the decision to march appealed to a different strategy. The march left from the Holot Detention Center and arrived in Jerusalem three days later. Sudanese and Eritrean asylum seekers had been held in detention for two years for illegal entry in the immediate aftermath of their arrival in Israel. As Moniem explained in the above-mentioned quote, as they were detained in the closed Saharonim facility, their dialogue with the administration was at an impasse, but their transfer from the closed Saharonim prison to the Holot "open facility" ${ }^{23}$ revealed a new resource: the ability to leave in the mornings and afternoons. As Moniem relates, they chose first to resort to a hunger strike, a well-known mode of action among the so-called "powerless" and the locked-in (Siméant, 1998, 2009) - before opting for a different strategy: marching towards the main institutions of the Israeli state - the Knesset and the High Court. He recalls how they reached the decision to march:

21. See footnote $n^{\circ} 16$.

22. The choice of this repertoire of action is also intrinsically linked to the architecture Egyptian asylum process, within which the UNHCR theoretically holds most of the institutional powers regarding refugees.

23. The Holot Detention Center is officially called an "open facility" as asylumseekers can leave the centre from morning to dusk. Having the Holot administration give up a roll call that had previously been taken at 12 p.m., thereby allowing them to be out for eight or so hours in a row, was one of the success of the mobilization in Holot. 
"We decided to go on a hunger strike until the following Sunday. To have the government visit us and talk with them, until they figured out what to do. So we staged the strike on the Friday, the Saturday, and the Sunday. (...) On Sunday at 10 , the immigration office opened and we went to see them. We asked why we were still in prison and they asked us why we were not eating any more. We told them that we should not be in jail because we were not criminals. We told them we were on a hunger strike to find out what was going on with our files. (...) The person told us that she had nothing to do with the granting of asylum status, that she was only responsible for feeding us. We gathered again with the Sudanese, and we said that the immigration had no solution to propose to us. When I saw people's faces, I thought that it was time for a revolution. (...) I told them that we had no other option but to go and see the Supreme Court or the Knesset. Everyone responded with one voice and agreed that we should go.

- Who chose to go to the Supreme Court and the Knesset?

- I did. The Supreme Court because they had cancelled the amendment to the anti-infiltration law, and the Knesset because they had adopted the amendment." 24

The group started marching from the heart of the dispute - the Detention Center. ${ }^{25}$ As they had experienced nothing but prison since their arrival in Israel, they did not know how to reach their final destination. It had not yet been decided whether to go to Tel Aviv or Jerusalem. On the first night, they reached Beer Shiva, where many activists and supporters joined to support them. It was during that first night in Beer-Shiva that the movement found its initial name: the "Walk for Freedom and Humanity", as Moniem explains:

"The posters had arrived for us to write on. People asked me what we should write. I said that we should write "Walk for Freedom and Humanity". I remember that I wrote posters with "Walk for Freedom and Humanity" on them. I did not write March because there had been a lot of Marches in history, so I wanted to write "Walk". (...) But I did not want people to associate this March with the big marches of Martin Luther King. So I wanted us to get a different name. Because back then, people were American citizens and wanted their rights as citizens to

24. Interview with Abdul Moniem, April 2015, Netanya, Israel.

25. Omer-Man M. (2013), "In act of civil disobedience, 150 Sudanese refugees walk out of Israeli 'open prison'", +972 , December $16^{\text {th }} 2013$. http://972mag.com/sudanese-asylum-seekers-walk-out-of-open-prison-en-masse/83751/ (consulted on 23/11/2014). 
be recognized. And I didn't want the Israelis to associate our March with a fight of this kind, and I knew if it appeared as we asked to become Israelis, it would make everything worse. I don't want to scare them." ${ }^{26}$

By his references to the "important marches" of history, Moniem placed their march within a specific system of reference. The register being used here is one of peaceful civil disobedience, and Moniem referred to Martin Luther King and his heritage several times in our interview. Interestingly, he refused to have the Walk for Freedom directly linked with the demands of the Civil Rights movement in the United States in the 1960s, stating that they involved American citizens who wanted to be recognized socially as such, whereas in their case, Moniem describes the movement differently: not as a quest for citizenship, but as a search for belonging through the right to seek and obtain refuge for a certain period of time. Nonetheless, the march may be seen here as an instrument of civil disobedience, just as the marches in the United States were, in the sense that both groups were peacefully demanding that their rights should belong fully to their place of residence, either as citizens or as refugees. The categories are different, but the logic behind them remains virtually the same.

While they were spending the night in the Beer Shiva bus station (with special permission to remain until 5 a.m., when travellers began entering the building), the decision was finally made to go to the Knesset in Jerusalem rather than the Supreme Court in Tel Aviv. The second night was spent in a kibbutz, where they were welcomed and fed. On the third day of the march, as they arrived in Jerusalem, they settled in the square facing the Knesset building, and waited for parliamentarians to come down and talk to them. The location of the group, in a square in front of the main building where those who would decide on their fate as refugees worked, recalls a core aspect of the Mustapha Mahmoud sit-in: a desire to enter into dialogue with the main decision-making actor. The movement was quickly dispersed by the police. Black and white people were violently separated, as both Israeli and asylum seekers protesters who were present that day recalled to me. The group of asylum seekers was sent back to the Negev and locked up in the closed facility of Saharonim for several months as punishment for their action. ${ }^{27}$

In solidarity with their "brothers" fight against oppression and arbitrary detention, but also as a reaction to the growing fear among them that they would be sent to the newly-created facility at Holot, Sudanese and Eritreans in Tel Aviv organized a number of demonstrations between 28 December

26. Interview with Abdul Moniem, April 2015, Netanya, Israel.

27. See Interview with Sigal, May 2015, Tel Aviv, Israel; Interview with Abdul Moniem, April 2015, Netanya, Israel. 
2013 and January 2014, as well as a strike. ${ }^{28}$ For the first time in the history of the Jewish State, African migrants marched in the streets and temporarily occupied highly symbolic places in Israeli political history (Rabbin Square in Tel Aviv and the Knesset Square in Jerusalem), a form of respect for their host society's historical heritage. The multiple references to the World War II genocide as a comparison with the situation in Sudan and Darfur, or their dangerous crossing of the Sinai as a comparison with the escape of the Jewish people from Egypt, represented attempts to bridge their respective histories and paths, to foster a sense of common destiny and fate, and to enable identification with their plight.

Occupations of squares through sit-ins and marches were the two-principal means of action. Both were peaceful, highly visible, and symbolic. Settling in a square and marching in the streets are a means of staging spatial belonging, and when enacted by migrants, the repertoire of the march and occupation is not simply voicing a claim: it is also about carrying out an act of visibility through civil disobedience. They are not only demanding the right to stay: they are performing it at the same time.

\section{BUILDING REFUGEENESS AS A COLLECTIVE FRONT}

The construction of a "refugee group", based on shared trajectory, also supported visibility and self-staging. Federating individuals upon a common claim and on collective actions - Square occupation of the March, became a resource. This unity among the Sudanese community in Israel was not taken for granted, reflecting the important division lines structuring the Sudanese society back in their home country. When he addressed this challenge, Moniem referred to the importance of ethnic belonging as an obstacle to a refugee identity:

"The problem in Sudan is the tribes. The powers that be have always used them to divide us. This is a very important issue, because people do not see beyond their own tribes. People from Darfur, Blue Nile, and Kordofan. And we had to talk about it, because the important thing for us was all to gather as Sudanese. We were asking for asylum in Israel, so we had to be united in this fight. Our

28. In January 2014, mobilization took place through other types of action. A labour strike paralysed the food and hotel industries where African were widely employed for several days. At the same time, demonstrations and sit- ins were organized in Tel Aviv in front of the U.S., British and South African Embassies and the Israeli Ministry of the Interior. 
problem in Sudan is also a unique and common problem: it is the power structure that is making war against all of us. So we have a common objective. It is important when people have a common objective that they all work together." ${ }^{29}$

It was therefore a conjugation of factors that led the Sudanese to associate with one another and to present a unified front for all (Sudanese) refugees both in Mustapha Mahmoud Square and in Israel. The goal was to define another form of belonging, one that was no longer based on representation and identity back in Sudan, but on a renewed political identity, that of refugees.

When asked about who was present in Mustapha Mahmoud square, Ali told us: "It was only Sudanese. Sudanese from the South, Darfur, the North, Nuba. We were all there." ${ }^{\prime 30}$ This quote illustrates how the sit-in gathered the Sudanese community together beyond religious or ethnic divisions, and created a collectivization of individual claims. The newly-constituted group was also defining itself against the "Other": they were all Sudanese, but it was "only Sudanese". The changes in the UNHCR's recognition and resettlement policies targeted all Sudanese, and so the feeling of "non-belonging" affected the whole of Sudanese society. The peculiarity of the Sudanese compared with other nationalities became a federating factor.

In Israel, the Sudanese and Eritreans, who were facing the same anti-infiltration law and rhetoric, gathered in shared opposition to the newly-adopted legislative provisions. The movements that rose up after the second amendment to the anti-infiltration law were initially primarily driven by Sudanese, underscoring a tradition of opposition associated with their national history. In order to achieve a common strategy based on a shared interest and identity, existing antagonism and divisions had to be overcome. Firstly, there were differences between the Sudanese who had arrived directly from Sudan and those who had come from Libya or Egypt, as they had different experiences of exile. An underlying conflict also set the Sudanese who had participated in the Mustapha Mahmoud sit-in a few years earlier against the rest of the Sudanese community, especially Darfurians (see Section III).

Secondly, cooperation needed to be achieved with the Eritreans, who made up the largest African migrant community in Israel. Language barriers, along with different traditions of activism, had to be overcome. Both communities organized with community leaders through a system of representation, as Musa, who was a leader of the Sudanese team, explained: "It was not easy to agree on anything - on the strike, on the demonstration. But we were organized into teams. We had the Sudanese strategic team and the Eritrean strategic team. What this meant was that the two teams would meet every day

29. Interview with Abdul Moniem, April 2015, Netanya, Israel.

30. Interview with Ali, February 2013, Cairo, Egypt. 
to agree." 31 The cooperation between Sudanese and Eritreans was a reasoned decision taken not only to facilitate common actions, but also to foster mobilization by ensuring representation and participation of each community.

Despite the initial divisions, consensus was achieved and based on a sense of common interests. As Taj explains,

"What helped more than these differences was the creation of one community for people to realize that tribal or ethnic divisions were pointless and that we needed one common strategy for our common problem. (...) It was about understanding how to work as a group. Even though people were saying 'OK, let's work together', it was still not easy to come to an agreement immediately. Everyone was like 'why them? And why not us? Why them? And why not us? (...) Why do we need to be working together? Because one single voice will be heard clearly and strongly. So we need to stay together." 32

Taj underscores once again the importance of the identity the target of public policies to foster collective mobilization and action. In both cases, a broad-scale mobilization helped foster more support within the communities, and the group became a resource. Refugeeness is constructed as a collective feature to identify a way out of the logic of asylum demands and individuals' administrative paths. The constitution of the group was fragile, however, and remained highly dependent on the target of public policies; indeed, when the Israeli government adopted a policy that targeted Sudanese and Eritreans in different ways in 2015, the notion of the "collective" was severely threatened.

\section{THE TEMPTATION OF AN EXIT: MOBILITY AS A FORM OF CONTESTATION}

In our two cases, mobilization failed to achieve the demands and a "political victory". The voicing and visibility strategy, as we will see in this section, did not provide them with the acknowledgment as refugees they were claiming. According to Hirshman, however, the "voice" is not the sole possible way of coping with discontent. Exit and loyalty are two alternative modes: in the first case, an individual escapes possible contestation, while in the second, he accommodates discontent through his loyalty to the power structure. One might wonder, however, if an "exit" - understood literally as an exit from a country - may not, in fact, be a form of contestation. In other words, when faced with the impossibility that a specific population group will be heard or that it can take its fate into its own hands, asylum seekers and statutory 
refugees resort to exit strategies. Mobility can be a remedy to their plight and discontent as a way to look for new answers. Can mobility and exile therefore be viewed as a form of social contestation? In this sense, we highlight the polysemy of the term "movement" as understood in both a political register (a group of political actors) and a kinetic sense (a passage between points on the globe) (Mitropolous and Neilson, 2006). As the authors recall, "it is not only the struggles of detainees that need to be understood as politically significant but also the momentum of migration as such" (ibid.).

\section{LEAVING EGYPT FOR ISRAEL}

On 22 December 2005, almost three months into the sit-in, the UNHCR attempted to negotiate a compromise, which was rejected by the protesters. ${ }^{33}$ On 30 December 2005, a large number of police gathered around Mustapha Mahmoud Square. Although their presence was a daily occurrence, there were more of them than usual. Faced with the refusal of the protesters to evacuate the square, the Egyptian police and armed forces violently drove the protesters out using water cannons and real bullets. Estimates of the death toll range from 20 to 50, including leaders of the group and children (REF). There were mass arrests: according to the Sudanese human right monitoring group, 1,280 people were arrested and taken to military camps or Amn El Markazi facilities (Central Security). A few months after this tragic conclusion, the road to Israel emerged as a new possibility.

Interestingly, this path, and the very idea of going to Israel, had not been present as a strategy in Egypt prior to Mustapha Mahmoud. It was in the aftermath of the mobilization that a growing number of people began crossing the Sinai to reach the Negev Desert. The gradual institutionalization of this route led to a growing number of entries, until the border was closed off with a wall in 2013. Can we therefore look at this mobility as a form of "exit discontent" after the tragic end to the Mustapha Mahmoud sit-in?

Ilham, a Sudanese asylum-seeker who arrived in Egypt in 2003, chose to go to Israel soon after being evicted from Mustapha Mahmoud Square, where she had been staying:

33. Sudan Tribune (2006), "Sudanese won't be deported - Egypt", January 3rd, 2006, http://www.sudantribune.com/spip.php?article13366 (consulted on 23/11/2014). 
"I had been registered and recognized (in Cairo) in 2003. I had the blue card (the refugee card) back then. I had it before Mustapha Mahmoud. But I was waiting for resettlement. Before Mustapha Mahmoud, they had closed everything. So, people left: we would hear that the United Nations worked better in Israel, and that they would let people travel to the U.S., Australia, and Canada. So I left." ${ }^{134}$

In common with many others like her, she waited for a few months after the end of the mobilization, hoping for a change in UNHCR policy. It was the concomitance of a lack of improvement in their situation in Egypt and the growing attraction of Israel that led to the institutionalization of this road to Israel.

Mohamed, who lived in Egypt in the 2000s, and with whom I talked outside the Holot Detention Center in 2015, recalled:

"After Mustapha Mahmoud, it all became much more complicated. That is what pushed us to come to Israel. They would take our yellow and blue card (the asylum-seeker and statutory refugee card respectively), and everything had to be done again. When we came to Israel, we wanted to find a more active UNHCR office than the one in Cairo. What we got was two years of prison".

In these two interviews, we clearly see that the desire to leave Egypt for Israel was a means of going to a place where UNHCR procedures would work properly. ${ }^{35}$ The request to be governed by working procedures is exactly the same reason that had led them to gather in Mustapha Mahmoud Square. ${ }^{36}$ While the means of action (visibility versus exit) was obviously different, it was similar in nature, as it was a way of achieving what they perceived to be their rights as asylum-seekers: to have their applications processed and to find a place where they could belong. Here, the "exit" is a way of criticising and censuring UNHCR policies as they were implemented in Cairo, and this sense, it may represent a form of social contestation.

34. Interview with Ilham, March 2015, Cairo, Egypt.

35 . Back then, the international organization was in charge of asylum seeker status in Israel, before transfer of competence to the State in 2009.

36. This calls into question the UNHCR's share of responsibility for the malfunctioning of asylum processes in Egypt and elsewhere: some might argue that responsibility lies with the states, hosts, resettlements, and others. One argument in support of this view is that the refugees from Egypt who sought better asylum conditions in Israel did not have a more convincing experience with regard to the UNHCR in Tel Aviv. 


\title{
LEAVING TO "VOICE" ELSEWHERE? \\ THE DIFFICULT TRANSNATIONAL REINVESTMENT OF MOBILIZATION
}

As a result of my interest in the "exit" strategy as a means of mobilization and contestation, I questioned the way in which it might potentially give rise to transnational mobilization in greater depth. In other words: were the refugees who had been participants in the Mustapha Mahmoud occupation still mobilized within the new movements in Israel, and if so, were they operating a form of transnationalization of mobilization for their right to refugee status? Most of my interviews proved this hypothesis to be wrong, and highlighted an important feature of mobilization: the dynamic of demobilization. The importance of demobilization among the formerly Egypt-based refugee group in Israel, diminishes the contentious aspect of the exit strategy.

The reasons for not protesting in Israel given to me by former Mustapha Mahmoud protesters were many. Saleh, for example, was highly sceptical about a positive outcome to the mobilization in Israel, which was affected by the inability to influence UNHCR policy in Egypt (the UNHCR only reopened procedures for Sudanese in 2012). In his view, the mobilization actually helped the re-election of ultra-nationalist parties in the 2015 election, as the sudden visibility of thousands of refugees proved too much for Israeli society:

\begin{abstract}
"Myself, I did not want the demonstrations to happen. Those who went to Jerusalem had no demands. Anyone who demonstrates must have a clear demand. (...) What was their goal? The goal was media propaganda, if you let the Sudanese in the country, at some point they will be dangerous for the ideology of the country. Look now, they are even holding demonstrations. For now on, they will ask for rights. They have created fear between refugees and any Israeli. If you were Israeli, what would you do if you saw 50,000 Sudanese marching in the street? The goal for the March was to create problems between us and the citizens. The elections used what happened widely; that was the goal. Netanyahu benefited from that through the propaganda machinery, especially Channel 2 . He used it to make for people vote for him." And to conclude, between optimism and pessimism: "People had been in Egypt five years or more before Mustapha Mahmoud. There are appropriate moments for that kind of things to happen. Here, I think the time has not arrived to do this kind of things. When people have been here for ten years or more, maybe..."37
\end{abstract}

The trauma experienced by the Mustapha Mahmoud protesters created a shift among those who had experienced the sit-in and the deadly expulsion. They perceived the new group as being made up of inexperienced people

37. Interview with Saleh, April 2015, Holot Detention Center, Israel. 
who were still hoping for the best, while they had lost the hope and idea that collective mobilization might lead to a positive outcome. Mohamed shared that impression with me, as we talked outside Holot:

"Israel and Holot, it is better than what we experienced. Those who came to Israel later did not live through Mustapha Mahmoud. They do not know what it was. Even the demonstrations that happened here have nothing in common with it.

- Did you go to the demonstrations?

- No, I told people not to. I told them I knew how it would end. I had seen violence before. I knew."

Saleh, who chose not to attend any of the collective events that were organized, explained that the outcome - detention - made the mobilization pointless:

"I did not attend anything. Why? For me, it is a business. People make others go to demonstrations, but they do so with a precise goal. At that point, there were 3,000 Sudanese (in Holot). When you come, you can take 1,500 people to go and march, and then they are all sent to Saharonim. You make them suffer and what do people get? Nothing. Personally, I have no benefit from that whatsoever. The ones who are those that put you back in jail. Me, I benefit from nothing. And not did those who were in Saharonim for three months. But the government's message is sent to the media" ${ }^{38}$

If demobilization is related to a perception of the high cost of the Mustapha Mahmoud sit-in, we should also take an in-depth look at some of the social characteristics of those who did mobilize. At the time of Mustapha Mahmoud in Egypt, most Sudanese refugees were from the Southern and Nuba regions of Sudan. A much smaller number was arriving from Darfur at that stage. In 2013 and 2014, the percentage changed: while many Nuba remained in Israel, Southerners went back home after independence in 2011. The largest share was Darfurians, who had not lived in Egypt previously and had not experienced the Mustapha Mahmoud occupation. As a result, an ethnic component comes into play with regard to who actually mobilized.

The reluctance of the Sudanese "from Cairo" to participate in collective actions with the rest of the Sudanese community also has its roots in the perception that Darfurians had taken over the political scenario. A significant portion of the Egyptian Sudanese community withdrew from Sudanese affairs

38. Ibid. 
as a reaction to the over-representation of Darfurians in the leadership. This was also seen as an injustice that was unfair to their specific, long-standing experience of asylum systems and migration processes over more than ten years. This type of disruption within the "collective identity" ideal discussed above underscores its fragility and a revival of national divisions based on both ethnicity and differing experiences of migration. Nonetheless, the Mustapha Mahmoud massacre was part of a collective memory, and was turned into a symbolic resource. My discussions with Sudanese in Israel who had not lived in Egypt and had not participated in the sit-in showed that its impact on their will to mobilize was significant. Everyone knows about Mustapha Mahmoud, about what the Sudanese might achieve, even though repression and the dangers of life in Egypt are very well-known.

\section{LEAVING ISRAEL FOR EGYPT}

The sensation that the demonstrations had "failed' left many people highly disappointed. Many of the Sudanese I met described a failed hope of seeing their demands satisfied: for them, a democracy was a place where one's discontent could be expressed, and where a government would satisfy one's claims as early as possible. When new amendments made the anti-infiltration law harsher, they felt that they had no resources in the face of the powerful state structures. During my fieldwork in March 2014, a couple of month after the major January demonstrations, it seemed to me that the will to fight the anti-infiltration amendment had been lost. People were discouraged: many had lost their jobs following the strike, and could no longer see the value of such a costly engagement.

Nonetheless, a second march left the Holot Detention Center in June 2014 to protest against arbitrary indefinite detention. Interestingly, this march left Holot for the Egyptian border, which is a few kilometres from the Detention Center. ${ }^{39}$ While it is not certain that the marchers actually intended to return to Egypt (by means of an improbable opening of the border or an even more improbable forced passage across it), the symbolic aspect was very powerful. This march became a symbol of their difficult living conditions in Israel, up to the point where despite Egypt's poor reputation as a refuge (the repression at Mustapha Mahmoud, the dramatic people-trafficking events in Sinai, etc.), they preferred to cross back, as if to say "if Israel can't provide us with asylum, then let Egypt take us back". The state's response was to use violent methods

39. The marchers stopped temporarily in a small park called Nitzana, two hundred metres from the Egyptian border, unsure of the outcome of their action. After a fortyeight-hour sit-in, they were violently expelled by IDF officers. The images are reminiscent of the tragic outcome of Mustapha Mahmoud, although no one died. 
to disperse the peaceful protestors who had gathered in Nitzana park overlooking the border. ${ }^{40}$ The symbolism of these men sitting in a park being evicted by the IDF underscored the disproportionate response by the ruling regime to a peaceful, and yet "disobedient" 41 demonstration, as was also the case during the repression of the occupation of Mustapha Mahmoud Square.

The ongoing detention policy, the failure of the Nitzana March, and the constant pressures exerted by the Israeli police guards at the Holot Center have pushed many people to resort to Israel's "voluntary return" process. When we met in Cairo, Omar, a Darfuri refugee who participated in the January demonstrations and the Nitzana march after being sent to Holot, recalls how he chose to leave Israel to return to Egypt ${ }^{42}$ :

"I told them everything when I arrived in Israel. About me, my life in Sudan, the conditions in Sudan. How can they tell me I am not a refugee? The Israeli government should have helped me. No one asks for asylum for no reason, no one. It is the circumstances that give us no other choice. So we did the demonstration. We stayed there (at the Israeli-Egyptian border) for three days. And we were locked in for three months. Then the Court decided that the government should close Holot. So they started pressuring people to have as many as possible leave Israel before the closure of the Center. They were telling us that we had nothing, that we were not welcome in Israel, that we had done something, bad, something illegal. They were threatening us, almost. I had no other choice. So, I told myself, OK, the best way is to close my file and leave. When they took me to jail (after participating in the Nitzana march) they left me in Beer Shiva for a month in a room with no light. So I decided to go. And closed my file". ${ }^{43}$

40. The violence of the reprisals at the border during this march echoes others, and underlines the extent to which border states form an ultra-sensitive red line with regard to both the weight of the border in a bilateral dimension and potential border disputes. See, for instance Badmon (2011).

41. I am referring here to civil disobedience theories.

42. Israel does not send refugees back to Egypt, but to Uganda and Rwanda, with whom it has arranged specific voluntary return programmes (despite the fact that none of the asylum-seekers who are sent back are from either of these two countries). The usual route goes from Israel to Uganda or Rwanda by air, after which people are smuggled to Juba in South Sudan, before crossing from there to Sudan and reaching Cairo illegally. Because of the high levels of mistrust and the lack of political relations between Israel and Sudan, it is extremely dangerous for Sudanese who have sought asylum in Israel to remain in Sudan, notwithstanding the prior motives that drove them from their own country.

43. Interview with Omar, October 2015, Cairo, Egypt. 
Like Omar, many people have left Israel since 2014. Of the 15,000 Sudanese residing in Israel before the demonstrations, about 7,000 remained in the country. ${ }^{44}$ The Netanyahu government was inflexible, and stated that the refugees and pro-refugee movements would have no impact on Israel's asylum policy. The individual difficulties faced by every migrant weakened the strength of the group and its collective actions, and highlighted the cost of mobilization. The multiplication of the numbers of "invitations to Holot" 45 and the detention faced by those who marched from the Centre to the Egyptian border are among the main elements that reduced the will to oppose. Other initiatives have continued and diversified, however: the annual ceremony to commemorate the continuing genocide in Darfur is still held and some Sudanese have obtained higher education diplomas and work in position of responsibility in some of the associations that support their cause. Through forms of more "loyal" strategies, some have chosen to influence Israeli society.

\section{CONCLUSION}

This article has dealt with refugee-led mobilization. I have attempted to question any alleged "improbability" of their political engagement through two cases of exclusion from a community of rights to which they are entitled to as refugees, both of which led to collective mobilization. Furthermore, this mobilization generated a resource that is invested by the migrants within their struggle: a symbolic and collective resource, a largely federated "refugee group" engaging in highly visible and emblematic actions.

This choice of voicing and visibility that I have addressed in this article also reveals a powerful desire to reverse stigma. Voicing was thought to be as a strategy for changing a predominant representation that they saw as a mistaken representation of them. Often, precarious populations are presented as voiceless, in the Bourdieusian sense of being talked about rather than doing the talking. They are not voiceless, however: they are made voiceless, confirming the diagnosis proposed by Stierl et al. (see my introduction). The power structure shut down their protests down, but their visibility strategy allowed their voices to come to the forefront - albeit temporarily, before they

44. Hotline for Refugees and Migrants, 2015, "Deported to the unknown", Online Report. URL: http://hotline.org.il/en/publication/deported-to-the-unknown-2/ (last consulted on 12/01/2017).

45. This is term used by the Israeli administration to describe the document given to asylum-seekers when they try to renew their residency permit ordering them to go to the Holot Detention Center. The use of the name "invitation" is, of course, seen as very ironic by those affected by the detention order - which by using this label (invitation) pretends not to be one. 
were sent back behind the curtain. Finally, voicing was also meant to present them as "refugees" in need of a status and protection, and in the end, as rights-holders.

I have concluded that these movements were attempts to promote and defend a specific form of belonging. The refugees did not attempt to become - nor did they hope to become - Egyptian or Israeli citizens; their goal was not to belong to the national community as citizens, but to be recognized as refugees, and in that sense as lawful temporary co-residents, sharing a common environment. Their constant references to international law, the UNHCR, and state responsibilities in matters of asylum confirmed the structure of international asylum regimes. Their belonging is therefore a belonging to what they view as an international community of refugees, under the responsibility of the international protection regime.

Last but not least, the aim of this article has been to suggest a potential transnational element of the struggle for belonging. The disengagement of former participants in the Mustapha Mahmoud sit-in highlights the difficulties with re-engagement with contentious politics after a violent and traumatic experience. The fact remains that the occupation of the square in Cairo was a very-well known event for all the Sudanese I interviewed, even those who had never lived in Egypt and did not take part in the sit-in. I will therefore conclude by saying that every demonstration and every occupation, even if evicted or blocked, leaves a spectral presence behind, and the promise that it will appear again at another time, and in another place. As such, scientific literature has not yet fully appreciated the growing importance of migrants' struggles nor their potentially transnational characteristics.

\section{BIBLIOGRAPHY}

Al-Husseini, J. \& Signoles, A., 2009, «Construction nationale, territorialité et diasporisation : le cas palestinien», Maghreb-Machrek, 199/1, pp. 23-42.

Anteby-Yemini L., 2008, "Migrations africaines et nouveaux enjeux de la frontière israélo-égyptienne.» Cultures \& Conflits, 72, pp. 77-99.

Arendt H., 2010. L'Impérialisme : Les Origines du totalitarisme, Paris: Points.

Badimon, M.E., 2011, « Où sont les diplômés chômeurs? » Confluences Méditerranée, Vol 3. No. 78, 77-91.

Baser, B., 2015, "La diaspora kurde d'Irak au Royaume-Uni », Hommes \& migrations, Vol 1307, pp. 140-143.

Bayat, A., 2009, Life as Politics: How Ordinary People Change the Middle East, Stanford: Stanford University Press.

Brand, L.A., 2006, Citizens Abroad: Emigration and the State in the Middle East and North Africa, Cambridge: Cambridge University Press. 
Brücker, P. 2013, The Waiting Zone - Political intentions and social impacts of the attribution of the refugee status to Sudanese migrants in Egypt - 2004-2013, Mémoire de master de recherche Sociologie Politique dirigé par C. Wihtol de Wenden, Sciences Po Paris.

Brücker, P., 2015, "Israel and its "Infiltrators": Reflecting upon a political crisis", Noria Research.

Dobry, M., 2009, Sociologie des crises politiques. La dynamique des mobilisations multisectorielles, Paris: Les Presses de Sciences Po.

Gonzales, A., 2009, "The 2006 Mega Marchas in Greater Los Angeles: CounterHegemonic Moment and the Future of El Migrante Struggle", Latino Studies, Vol. 7/1, pp. 30-59.

Grabska, K., 2006, "Marginalization in Urban Spaces of the Global South: Urban Refugees in Cairo", Journal of Refugee Studies, Vol. 19/3, 287-307.

Haddad, E., 2008, The Refugee in International Society: Between Sovereigns, Cambridge: Cambridge University Press.

Harrell-Bond B., 2006, «Le drame de la place Mustapha Mahmoud au Caire raconté par Barbara Harrell-Bond», Recueils Alexandrie, Collection Reflets. Consulted on 14 December 2016, URL: http://www.reseau-terra.eu/article553.html.

Hmed, C., 2009, «Espace géographique et mouvements sociaux», Dictionnaire des mouvements sociaux, Paris: Presses de Sciences Po, pp. 220-227.

Human Rights Watch (2014). "Make Their Lives Miserable. Israel's Coercion of Eritrean and Sudanese Asylum Seekers to Leave Israel". Consulted on 15 December 2016, URL: https://www.hrw.org/report/2014/09/09/make-theirlives-miserable/israels-coercion-eritrean-and-sudanese-asylum-seekers

Isin, E.F., 2009, "Citizenship in flux: The figure of the activist citizen", Subjectivity 29/1, 367-388.

Jaulin, T., \& Smith, E., 2015, «Généralisation et pratiques du vote à distance. Introduction thématique», Afrique Contemporaine, Vol 4, pp. 11-34.

Jounin, N., 2014,

Lamarche, K., 2013, Militer contre son camp? Des Israéliens engagés aux côtés des Palestiniens, Paris: PUF.

Mathieu, L., 1999, «Une mobilisation improbable: I'occupation de l'église Saint-Nizier par les prostituées lyonnaises», Revue Française de Sociologie, 40/3, pp. 475-499.

Matonti, F. \& Poupeau, F., 2004, "Le capital militant. Essai de définition», Actes de la Recherches en Sciences Sociales, 155/5, pp. 4-11.

Migreurop, 2006, Guerre aux migrants. Le livre noir de Ceuta et Melilla.

Mitropolous, A., \& Neilson B., 2006, "Exceptional Times, Non-governmental Spacings, and Impolitical Movements", Vacarme, 34. Consulted online on 15 January 2017, URL: http://www.vacarme.org/article484.html.

Néfissa, S.B., 2007, "'Ça suffit' ? Le 'haut' et le 'bas' du politique en Égypte», Politique Africaine, 108/4, pp. 5-24.

Neveu, E., 2011, Sociologie des mouvements sociaux, Paris: La découverte.

Nicholls, W.J., 2013, The DREAMers: How the Undocumented Youth Movement Transformed the Immigrant Rights Debate, Stanford: Stanford University Press. 
Oliveri, F., 2015, "Subverting neoliberal citizenship. Migrant struggles for the right to stay in contemporary Italy" ACME, 14/2, pp. 492-503.

Ottavy, E. \& Clochard, O., 2015,

Pette, M., 2016, "Venir en aide aux migrants dans le Calaisis», Savoir/Agir, 36/2, pp. 47-52.

Sayad, A., 1999, La Double Absence. Des illusions de l'émigré aux souffrances de l'immigré, Paris:Le Seuil.

Shami, S., 1996, "Transnationalism and Refugee Studies: Rethinking Forced Migration and Identity in the Middle East", Journal of Refugee Studies, 9/1, pp. 3-26.

Sheffer, G., 2003, Diaspora Politics. At Home Abroad, New York: Cambridge University Press.

Siméant, J., 1998, La cause des sans-papiers, Paris: Presses de Sciences Po.

Siméant, J., 2009, La grève de la faim, Paris: Presses de Sciences Po.

Vannetzel, M., 2008, "Les voies silencieuses de la contestation: les Frères musulmans égyptiens, entre clientèlisme et citoyenneté alternative», Raisons Politiques, 29/1, pp. 23-37.

Veron, D., 2014, "Cartographie de la frontière et topographie clandestine», Hommes \& Migrations, Vol. 1304, pp. 19-25.

Vertovec, S., 2005, "The Political Importance of Diasporas", Centre on Migration, Policy and Society Working Paper No. 13, Oxford: University of Oxford. 